\title{
Diversity of Coryneforms Found in Infections following Prosthetic Joint Insertion and Open Fractures
}

\author{
Summary: In a 5-year period, 73 coryneform isolates from prosthetic joint and open \\ fracture infections in 60 patients treated in a hospital specialized in orthopedic surgery \\ were speciated. The most frequent species were Corynebacterium amycolatum, Coryne- \\ bacterium striatum, Corynebacterium diphtheriae biotype mitis, and Corynebacterium \\ jeikeium. At least 14 isolates were deemed clinically significant as sole agents of infection.
}

\section{Introduction}

Infections following prosthetic joint insertion and open fractures have been reviewed in the immediate past by various authors [e.g., 1-5]. We have been surprised, however, about the paucity of coryneform organisms reported in such infections. The main agents have been coagulasenegative and -positive staphylococci, followed by various streptococci and gram-negative rods [1-5]. A few reports have mentioned "anaerobic corynebacteria" [6] or Propionibacterium acnes [4], some have reported non-speciated "diphtheroids" $[1,2]$, and a few did not find any such bacteria $[3,5]$. In our pursuit of infections with coryneforms [7], we thought it worthwhile to speciate a collection of coryneforms that one of us (L. F.) has isolated from those infections since 1992.

\section{Patients and Methods}

All patients reviewed had been admitted to the Endo Clinic in Hamburg, Germany, either for an exchange operation necessitated by infection of a prosthetic joint or for correction of an infected open fracture (exogenous osteomyelitis). Generally, a preoperative aspirate was taken from the infected area, material was scraped from the area of infection intraoperatively and postoperatively; drainage fluid was obtained as well. All samples were Gram-stained, inoculated into Brain Heart Infusion (bioMérieux, Marcy I'Etoile, France), TVLS Medium [8], the set of media devised by Lodenkämper [9], aerobic $\left(5 \% \mathrm{CO}_{2}\right)$ Columbia blood agar, and anaerobically incubated Brucella Agar, both with $5 \%$ sheep blood (bioMérieux). If there was growth in the liquid media $[8,9]$, they were subcultured to those aerobic and anaerobic blood agar plates as well. Isolates were kept on Brain Heart Infusion (bioMérieux) slants. They were identified as to species by a scheme elaborated by two of us [10]. Susceptibility testing was done by the DIN method [11].

Clinical significance of the isolates was evaluated from the patients' records. All patients showed clear signs of infection as defined in an earlier study [6]. We judged as clearly significant those isolates that were found as monocultures in aspirates (most of these had been positive on direct Gram stains).

Questionable significance was assumed when coryneforms were isolated from scrapings or drains only. Mixed cultures were noted, but were not further evaluated for significance.

\section{Results}

In all, 73 isolates were recovered from 60 patients in a 5 -year period (Table 1). Fourty-one came from hip infections, 17 from knee infections, and 15 from variously located exogenous osteomyelitides. Fourteen isolates were deemed significant, 16 were deemed to be of questionable significance, and 43 were mixed with staphylococci, streptococci, and/or aerobically or anaerobically growing gramnegative rods.

Since our patients were referred from other hospitals, we were unable to determine whether prostheses previously placed contained antibiotics or not. For the same reason, incubation periods could not be determined with certainty; they varied from a few weeks to 2 years. At the Endo Clinic, no antibiotic prophylaxis was given for exchange operations (which involved antibiotic-impregnated acrylic cement) [6]. Nevertheless, 22 patients had received antibiotics for post-primary infections which we defined as those that were preceded by earlier (primary) ones. There were 39 primary and 34 post-primary infections.

The most frequent species involved was Corynebacterium amycolatum. Most isolates of this species were formerly classified as Corynebacterium xerosis [7]. This species is frequently multiresistant [7], particularly to those antibiotics often used in orthopedics (clindamycin, aminoglycosides, rifampin, and sometimes also to $\beta$-lactam antibiotics). The same may be true for the second most frequent species, Corynebacterium striatum [7], except that it is generally susceptible to $\beta$-lactams. Also often multiply antibiotic-resistant is the fourth most frequent species, Corynebacterium jeikeium [7]. It is interesting to note that all coryneforms isolated from the 22 patients who received preoperative antibiotics were multi-resistant.

Received: 18 August 1997/Accepted: 17 November 1997

Prof. Dr. A. von Graevenitz, Verena Piinter-Streit, Dr. med. G. Funke, Institut für Medizinische Mikrobiologie der Universität Zürich, Gloriastr. 30, CH-8028 Zürich. Switzerland; Dr. med. L. Frommelt, Mikrobiologisches Labor, Endo-Klinik D-22767 Hamburg, Germany. 
Table 1: Coryneform bacteria from orthopedic infections.

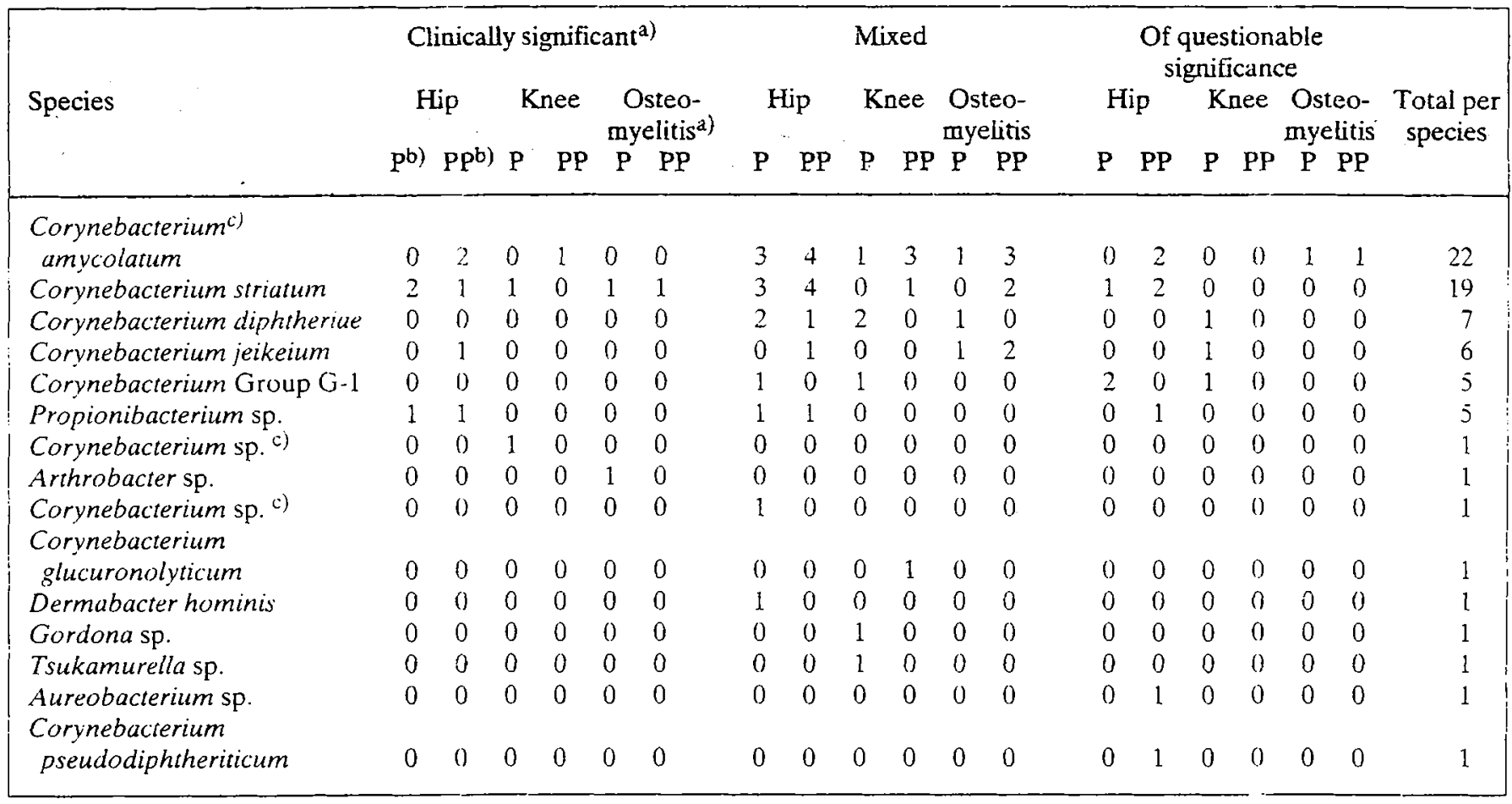

${ }^{a)}$ see text; ${ }^{b)} \mathrm{P}=$ primary. $\mathrm{PP}=$ post-primary; ${ }^{\text {c) }}$ unable to speciate.

The third most frequent species was, surprisingly, Corynebacterium diphtheriae. Although this will be the subject of a separate report, it should be mentioned here that the biotype of all isolates except one (gravis) was mitis, and that the ribotypes and antibiogram type corresponded to those found earlier in Switzerland [12]. Table 1 also lists further coryneforms, each of which was represented by one isolate only.

\section{Conclusion}

The literature on the subject lists only four single reports

\section{References}

1. Fitzgerald, Jr., R. H., Peterson, L. F. A., Washington II, J. A., van Scoy, R. E., Coventry, M. B.: Bacterial colonization of wounds and sepsis in total hip arthroplasty. J. Bone Joint Surg. 55-A (1973) $1242-1250$.

2. Inman, R. D., Gallegos, K. V., Brause, B. D., Redecha, P. B., Christian, C. L.: Clinical and microbial features of prosthetic joint infection. Am. J. Med. 77 (1984) 47-53.

3. Powers, K. A., Terpenuing, M. S., Voice, R. A., Kauffman, C. A.: Prosthetic joint infections in the elderly. Am. J. Med. 88 (1990) $9 \mathrm{~N}-13 \mathrm{~N}$.

4. Dietz, F. R., Koontz, F. P., Found, E. M., Marsh, J. L.: The importance of positive bacterial cultures of specimens obtained during clean orthopaedic operations. J. Bone Joint Surg. 73-A (1991) 1200-1207.

5. Bliss, D. G., McBride, G. G.: Infected total knee arthroplasties. Clin. Orthop. Relat. Res. 199 (1985) 207-214 of coryneform osteomyelitis on the extremities in which species were determined [13-16]. Four further reports are extant on cases of septic arthritis [17-20]. Our report shows that coryneforms are not rare in prosthetic joint infections and post-fracture osteomyelitides and that they may be causative agents in such infections.

\section{Acknowledgement}

We thank Pala Das, cand. med., for submitting and keeping the strains.

6. Buchholx, H. W., Elson, K. A., Engelbrecht, E., Lodenkämper, H., Röttger, J., Siegel, A.: Management of deep infection of total hip replacement. J. Bone Joint Surg. 63-B (1981) 342-353.

7. Funke, G., von Graevenity, A., Clarridge III, J. E., Bernard, K. A.: Clinical microbiology of coryneform bacteria. Clin. Microbiol. Rev. $10(1997)$ 125-159.

8. Caselitz, F. H., Freitag, V.: Halbflüssiges Kombinationsmedium (TVLS-Medium) zur Züchtung anaerober Bakterien. Aerztl. L_ab. 15 (1969) $426-430$.

9. Lodenkämper, H., Stienen, G.: Zur Therapic anaerober Infektionen. Dtsch. med. Wschr. 81 (1956) 1226-1231.

10. von Graevenitz, A., Funke, G.: An idertification scheme for sapid!y and aerobically growing gram-positive rods. Zbl. Bakt. 284 (1996) 246-254.

11. DIN Deutsches Institut für Normung e.V.: Empfindlichkeitsprüfung von Krankheitserregern gegen Chemotherapeutika. DIN 58940 und 
58944. DIN-Taschenbuch 222: Medizinische Mikrobiologie und Immunologie. Normen und weitere Unterlagen. 2. Auflage. BeuthVerlag GmbH, Berlin und Köln 1992, pp. 331-403.

12. Gruner, E., Opravil, M., Altwegg, M., von Graevenitz, A.: Nontoxigenic Corynebacterium diphtheriae isolated from intravenous drug users. Clin. Infect. Dis. 18 (1994) 94-96.

13. Claeys, G. Verschraegen, G., Desmet, L., Verdonk, R., Claessens, H.: Corynebacterium JK (Johnson-Kaye strain) infection of a Küntscher-nailed tibial fracture. Clin. Orthop. Relat. Res. 202 (1986) 227-229.

14. Chomarat, M., Breton, P., Dubost, J.: Osteomyelitis due to Corynebacterium group D2. Europ. J. Clin. Microbiol. Infect. Dis. 10 (1991) 43.

15. Weller, T. M. A., McLardy Smith, P., Crook, D. W.: Corynebacterium jeikeium osteomyelitis following total hip joint replacement. J. Infect. 29 (1994) 113-114.
16. Poilane, I., Fawaz, F., Nathanson, M., Cruaud, P., Martin, T., Collignon, A., Gaudelus, J.: Corynebacterium diphtheriae osteomyelitis in an immunocompetent child: a case report. Eur. J. Pediatr. 154 (1995) 381-383.

17. Guran, Ph., Mollaret, H.-H., Chatelain, R., Gropman, M., Prigent, F., Béal, G.: Arthrite purulente à bacille diphthérique atoxigène.Arch. franç. Pédiat. 36 (1979) 926-929.

18. Valenstein, P., Klein, A., Ballow, C., Greene, W.: Corynebacterium xerosis septic arthritis. Am. J. Clin. Pathol. 89 (1988) 569-571.

19. Booth, L. V., Richards, R. H., Chandran, D. R.: Septic arthritis caused by Corynebacterium xerosis following vascular surgery. Rev. Infect. Dis. 13 (1991) 548-549.

20. Damade, R., Pouchot, J., Delacroix, I., Boussougant, Y., Vinceneux, P.: Septic arthritis due to Corynebacterium diphtheriae. Clin. Infect. Dis. 16 (1993) $446-447$. 